\title{
Multiple precarity and intimate family life among African-Chinese families in Guangzhou
}

Citation for published version (APA):

Jordan, L., Hoang, A. P., Chui, C. H. K., Wang, W., \& Mazzucato, V. (2021). Multiple precarity and intimate family life among African-Chinese families in Guangzhou. Journal of Ethnic and Migration Studies, 47(12), 2796-2814. https://doi.org/10.1080/1369183X.2020.1739390

Document status and date:

Published: 10/09/2021

DOI:

10.1080/1369183X.2020.1739390

Document Version:

Publisher's PDF, also known as Version of record

Document license:

Taverne

Please check the document version of this publication:

- A submitted manuscript is the version of the article upon submission and before peer-review. There can be important differences between the submitted version and the official published version of record.

People interested in the research are advised to contact the author for the final version of the publication, or visit the DOI to the publisher's website.

- The final author version and the galley proof are versions of the publication after peer review.

- The final published version features the final layout of the paper including the volume, issue and page numbers.

Link to publication

\footnotetext{
General rights rights.

- You may freely distribute the URL identifying the publication in the public portal. please follow below link for the End User Agreement:

www.umlib.nl/taverne-license

Take down policy

If you believe that this document breaches copyright please contact us at:

repository@maastrichtuniversity.nl

providing details and we will investigate your claim.
}

Copyright and moral rights for the publications made accessible in the public portal are retained by the authors and/or other copyright owners and it is a condition of accessing publications that users recognise and abide by the legal requirements associated with these

- Users may download and print one copy of any publication from the public portal for the purpose of private study or research.

- You may not further distribute the material or use it for any profit-making activity or commercial gain

If the publication is distributed under the terms of Article $25 \mathrm{fa}$ of the Dutch Copyright Act, indicated by the "Taverne" license above, 


\title{
Multiple precarity and intimate family life among African-Chinese families in Guangzhou
}

\author{
Lucy Jordan, Andrew Pau Hoang, Cheryl H. K. Chui, Wei Wang \& Valentina \\ Mazzucato
}

To cite this article: Lucy Jordan, Andrew Pau Hoang, Cheryl H. K. Chui, Wei Wang \& Valentina Mazzucato (2021) Multiple precarity and intimate family life among African-Chinese families in Guangzhou, Journal of Ethnic and Migration Studies, 47:12, 2796-2814, DOI: 10.1080/1369183X.2020.1739390

To link to this article: https://doi.org/10.1080/1369183X.2020.1739390

View supplementary material $\asymp$

Published online: 07 Apr 2020.

Submit your article to this journal $₫$

Џ Article views: 619

Q View related articles

View Crossmark data $\nearrow$

Citing articles: 3 View citing articles 


\title{
Multiple precarity and intimate family life among African- Chinese families in Guangzhou
}

\author{
Lucy Jordan (D) ${ }^{a, b}$, Andrew Pau Hoang (D) ${ }^{a}$, Cheryl H. K. Chui (D) ${ }^{a}$, Wei Wang ${ }^{a}$ and \\ Valentina Mazzucato ${ }^{c}$ \\ ${ }^{a}$ Department of Social Work and Social Administration, The University of Hong Kong, Hong Kong SAR, \\ People's Republic of China; ${ }^{b}$ Center for Social Development of Africa, Faculty of Humanities, University of \\ Johannesburg, Johannesburg, South Africa; ${ }^{C}$ Faculty of Arts and Sciences, Maastricht University, Maastricht, \\ Netherlands
}

\begin{abstract}
Formal ties between China and several African states have intensified in recent years. Alongside growing economic and trade cooperation, the international mobility of people between China and African states is increasing. Recent studies have shown that African migrants face institutional barriers to integration in Chinese society, however, and the personal and social consequences of these barriers remain under-researched, especially the dynamics of intimate family life. Drawing upon concepts of precarity and 'low-end globalisation', this study examines how African-Chinese families navigate everyday life, including work, family and children's education. It is based on ethnographic fieldwork comprising observations and indepth interviews with African-Chinese families and one community leader $(n=19)$. These reveal how families confront the pervasiveness of legal, economic and social precarization in multiple overlapping domains. These social forces have intergenerational repercussions, with adverse impacts on family life, interpersonal relationships and sense of belonging to the local community. Yet precarity offers conditions for practices of empowerment. We conclude with implications for migration studies.
\end{abstract}

\section{KEYWORDS}

Precarity; migration; China; Africa; family

\section{Introduction}

Since the Forum on China-Africa Cooperation in 2000, formal ties between China and diverse African states have received growing attention. The intensification of 'SouthSouth' collaboration is exemplified by significant Chinese investment in development projects across Africa (Kuo 2015). Alongside intensified bilateral trade, international migration is increasing. Growing numbers of Chinese are migrating to Africa as Africans from diverse countries, including Senegal, Mali, Nigeria, Kenya, Ghana and DR Congo, migrate to China (Bodomo 2012). Although official statistics reported 11,000 Africans registered in Guangzhou in June 2016 (Wang and Liang 2016), scholars estimated the actual number to be between 20,000 ( $\mathrm{Li}, \mathrm{Ma}$, and Xue 2009) and 100,000 in the late 2000s, including registered and irregular/undocumented migrants (Bodomo 2015). In 
addition to economic migrants, China's Ministry of Education (2015) reported over 41,600 African students in China in 2014. The resident African migrant population in China fluctuates, with, for example, noticeable drops following police crackdowns and subsequent deportations that target those commonly described as sanfei ('three illegals'). ${ }^{1}$

A small but growing body of scholarship focuses on African traders in China, studying their working lives, encounters with Chinese merchants and authorities, and settlement patterns (Bodomo 2012; Castillo 2014; Huynh, Park, and Chen 2010; Lyons, Brown, and Li 2012; Mathews and Yang 2012). Topics range from interactions and mutual impressions between African migrants and local Chinese ( $\mathrm{Li}, \mathrm{Ma}$, and Xue 2009) to how the broader legal-political and social structures of Chinese society - including immigration policies and the media's negative portrayals of Africans - affect the lives of Africans in Guangzhou (Haugen 2012; Lan 2015a).

The formation of African-Chinese families in China (Haugen 2014) is an under-explored subject and is often limited to journalistic accounts (Marsh 2014). Some African migrants predominantly men - are establishing nuclear families through marriages with Chinese. Many of these families stay in China, but some may leave or send some members to African states. Existing immigration policy and local xenophobia towards Africans suggests adverse effects on romantic and marital relations between undocumented Nigerian men and Chinese migrant women from less developed regions in China (Lan 2015b).

Similar to the existing research, we found the Africans in this study mostly work as petty traders in China, sharing a marginalised position within the global division of labour. In Guangzhou, they mostly run shops that sell shoes or garments among different trading malls in the area of Xiaobei and Guangyuanxi. Regardless of legal status, they gradually develop local social networks, including forming families.

The present study aims to fill the research gap by examining how African-Chinese families in Guangzhou - usually composed of an African husband, a Chinese wife and their child(ren) - are shaped by experiences of precarity and processes of precarization (Alberti et al. 2018) in intimate family life and related domains, including employment, housing, children's education and relationships. These families are transnational in that they are formed by overlapping mobilities (Williams 2013). We argue they are not examples of a standard transnational family constellation, but rather reflect various configurations of intermarriage (Osanami Törngren, Irastorza, and Song 2016). Our findings offer empirical insight into this emerging population living at the crossroads of global mobility and intercultural exchange. Conceptually, we echo critiques that precarity cannot be collapsed into an all-encompassing, 'stable, undivided subject position' (Neilson and Rossiter 2008) and elaborate its unique legal, economic and social dimensions. In focusing on intimate family life, we further situate precarity in the context of local institutions and 'low-end globalisation': how vulnerability is experienced and activated in the increasingly diverse geopolitical site of contemporary Guangzhou.

\section{Precarity in the context of 'Low-End Globalisation'}

Bilateral economic ties are often foregrounded in public discourse concerning AfricaChina relations, while the influence of globalisation on communities and families in these movements of capital, goods and people is less emphasised. The mobilities of global professional elites and related flows of power and capital - typically Westerners 
and migrants from high-income countries who can negotiate 'fitting in' and 'opting out' (Cai and Su 2021, this issue) - are interpreted as 'high-end globalisation' (Mathews and Yang 2012; Ribeiro 2006). This also includes mobilities of the highly educated and skilled under 'intellectual migration' (see Lo et al. 2021, this issue). In contrast, the transnational flows of people and goods from the 'developing world', involving comparatively small amounts of capital, informal networks, temporary, semi-/extra-legal and small-scale transactions, are described by the concept of 'low-end globalisation' (Mathews, Ribeiro, and Vega 2012). China, as one of the largest suppliers of cheap goods to developing countries (Lin 2011), plays a critical role in low-end globalisation in transmitting flows of people, goods and capital between China and sub-Saharan Africa.

Since its conceptual beginnings in Bourdieu's (1963) writings on précarité, contrasting permanently employed workers with their intermittent/casual counterparts, the concept of precarity has taken on wider and more substantiated meanings. Precariousness, the unavoidable vulnerability that is a condition of sociality, is contrasted with precarity, which captures specific ways that socioeconomic and political institutions distribute the conditions of life unequally (Puar et al. 2012, 169; Butler 2004). Furthermore, processes of precarization highlight objective conditions, subjective experiences and heterogeneous perceptions of insecurity in employment (Alberti et al. 2018). For most workers in the global South, precarity has arguably always been the norm, even if it has not been called by this name (Millar 2017). Precarity has gained prominence in labour and citizenship studies, but also in migration scholarship (Schierup and Jørgensen 2016). Politically, the conceptualisation of precarity necessitates a shift from perspectives that view it simply as a manifestation of social exclusion (Jordan et al. 2017) or equate it with vulnerability (Millar 2017). Precarity serves 'an essential purpose in a disjointed political economy of neoliberal globalisation, within which the excluded are unsafe and vulnerable' (Schierup and Jørgensen 2016, 948). In such a conceptualisation, the excluded become valuable precisely because of their vulnerability, leading to exploitation (Bauder 2006). However, precarity is irreducible to the inscription of a vulnerable, victim narrative. It has been theorised to stimulate counter-processes of empowerment among Africans in China (Castillo 2016) and reflects the broader structural conditions wherein migrant labourers navigate and can overcome the 'frictions of mobility' (Feng, Zhu, and Wang 2021, this issue). This study's conceptual points of departure, then, are the conditions created within the spectrum of vulnerability and empowerment.

Conditions of precarity may activate practices of 'homing', for example Nigerian migrants striving to create a sense of home in Guangzhou despite the unpredictable and transient nature of their lives (Castillo 2016). Although conditions are sometimes difficult for African migrants, precarity 'functions as a trigger, encouraging individuals to develop structures of solidarity and networks of support' (Castillo 2016, 2-3) both in and outside the home, creating 'hopeful spaces of subjectivities' under conditions of neoliberalism and autocratic power (Gao 2021, this issue). The conditions of vulnerability and empowerment that precarity produces nest as structuring forces impacting not just upon labour, but other social institutions. Family practices qua homing under conditions of economic hardship and community violence illustrate how parents become flexible, resilient and enterprising to foster a sense of security for their children during precarious times in diverse global contexts (Harker 2012; Wilson and Yochim 2015). Security has been described by Boccagni (2017) as one key emotive element of the concept of homing. ${ }^{2}$ 
In this study, we argue that processes of low-end globalisation combined with local policies to create legal, economic and social conditions of precarity. African-Chinese families - conditioned by overlapping mobilities and low-end globalisation forces - are embedded within and affected by these dimensions of precarity. Our data offer a deeper insight into aspects of precarity's vulnerability and the fragility of homing practices within these constraints. We reflect briefly on the empowerment dimension of precarity where our data allow.

\section{Research method}

This study adopts a multi-method qualitative approach including document analysis of relevant legislation and policy briefs, media analysis, and in-depth interviews and field observations. Official documents on immigration, education, housing and employment capture the Chinese government's public stance towards African migrants and their families, and the broader structural and environmental contexts of intimate family life.

Purposeful snowball sampling identified 23 participants for in-depth interviews who were in African-Chinese couple relationships, at least 18 years of age and currently living in China. We define 'African-Chinese' families in the broadest sense and include diverse African nationals and Chinese women with experience of romantic, co-habiting, or marital relationships. Children had been born in most of these relationships, introducing an important intergenerational consideration to our analyses of family. Additionally, we selected five key informants to interview, representing community leaders, social services, and the legal and academic professions (see [blinded for review] for more details). The data collection process spanned ten months, from October 2015 to August 2016, in locations convenient to the participants. The research was approved by the Human Research Ethics Committee of The University of [blinded for review].

The current study draws on a subset of the data set (19 of 23). Of these 19 in-depth interviews (11 Chinese wives and seven African husbands, one African male key informant), three were audiotaped and transcribed verbatim (Table 1). Consent was sought prior to each interview. The majority of the participants were reluctant to be audiotaped, potentially reflecting cautiousness towards outsiders and concern about identification. When audiotaping was not possible, our research assistant took extensive field notes during and after each interview. Data were analysed thematically (Braun and Clarke 2006).

Field observations were conducted during regular visits to districts and commercial buildings where African migrants congregated to trade. A member of the research team also took part in informal gatherings, including football matches with local African teams. During the field research, extensive notes were also taken in contexts other than interviews and later analysed, including documentation of informal interactions between African migrants and local Chinese, and amongst Africans, recording the tone and mood of these exchanges, and other relevant observations such as police presence and trending topics on social media via platforms such as Weibo. These notes enrich the material derived from the document analyses and in-depth interviews with participants.

The composition of our research team is an important point to consider, given the interpretive and in-depth method of inquiry. The team consisted of multi-ethnic and multilingual interdisciplinary social science scholars. The primary fieldworker was a native of mainland China fluent in both English and Mandarin. The other research team members included a Hong Kong Chinese woman, two Caucasian women and a man of mixed Asian ancestry. 
Table 1. Summary of participant characteristics.

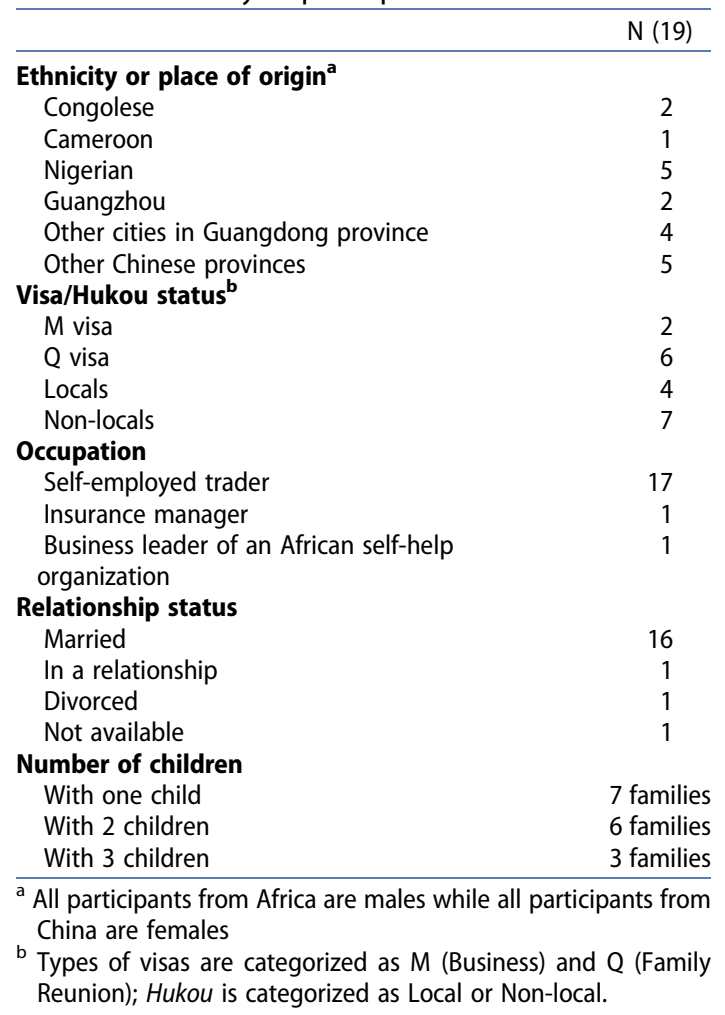

Triangulation of field methods captured different aspects of intimate family life, and inter-team coding and discussion strengthened the rigour, conceptualisation and contextualisation of the study.

As shown in Table 1, most of the African male participants were self-employed traders, with the exception of the leader of an informal community support organisation. Most of the African migrants who participated in this study were Nigerians, likely reflecting the clustering of Nigerians in trading areas (Mathews and Yang 2012), with the exception of one Cameroonian and two Congolese. Most of the Chinese women interviewed were themselves internal migrants. Apart from one female divorcee, all of the women were married to an African man at the time of interview. All but one participant had one or more children. These children were all relatively young, ranging from one month to nine years of age. The majority of the participants were living in Guangzhou with their children.

\section{Findings}

\section{Overlapping mobilities: Chinese domestic migrant woman meets African international migrant man}

The story of an African-Chinese family often begins with a narrative of overlapping mobility. Women from rural areas and smaller urban centres in China travel to large urban centres of production to join mobile circuits of migrant labour. Chinese migrant labour is concentrated in the metropolitan areas of Southern and Eastern China to produce 
goods destined for global markets. These areas also attract internationally mobile traders seeking to obtain these goods. For example, when Mrs. C met her Nigerian common-law husband, she had just left her first husband. She was working for a factory in Shenzhen with no potential for career development and feeling depressed. Upon meeting her husband - who later convinced her to stay in Guangzhou - she felt happy again.

Mrs P., another internal migrant, married to a Congolese man, speculated about the decision-making processes of Chinese women:

I sometimes wonder what made these girls agree to become involved in these relationships. Maybe they couldn't find [a] better life than the one they have. So, I would say it's about reality ... Some girls want a stable life. Some Africans, even though they don't have visas, they have stable [customers] ... The goal must be to strive for a better life. But not everyone succeeds. Sometimes they are willing to take shortcuts. This phenomenon exists in our society, either for foreigners or Chinese, right? (Mrs P., 6 August 2016)

For some Chinese migrant women, marriage with an African trader, especially a successful one, could raise their socio-economic status (SES). In our sample, around one-third of the Chinese wives (3/11) held either no college degree (Mrs N.) or a less revered college degree (Mrs L., Mrs P.). In China, degrees usually determine one's career development. Without their husbands' support, it would be difficult to afford an apartment and to pay for their children's education in major cities (e.g. Mrs L.'s daughter), where private schools can cost $70,000 \mathrm{RMB}$ a year $(£ 8,220)$. While the choice to enrol children in private school may reflect upwardly mobile SES trajectories for some, it is often a necessary response to policy and legal constraints that deny non-local hukou holders the right to receive free and compulsory state education.

\section{Legal precarity and the intimate family life of African-Chinese families}

The intimate family life of African-Chinese families intersects with China's legal apparatus (Zhu and Qiang 2021). Consistent with prior studies (Li, Lyons, and Brown 2012), we found that African men face difficulties applying for visas. Table 2 summarises the main types of relevant visas.

The Commerce and Trade $\mathrm{M}$ visa rarely exceeds one year, making it inconvenient, disruptive and costly for African migrants to engage in business or trade continuously, and they may overstay due to stringent requirements. While living, working and maintaining relationships, these men face an ongoing risk of deportation. Legally registered marriage permits these men to apply for the Q visa, but this does not grant foreign partners working rights. Those deported for engaging in business or employment activities without a valid

Table 2. Related types of visa.

\begin{tabular}{|c|c|c|}
\hline & Type of Visa & Chinese \\
\hline M & $\begin{array}{l}\text { Persons who come to China for commercial } \\
\text { trade activities (Business) }\end{array}$ & M 字签证, 发给入境进行商业贸易活动的人员 \\
\hline Z & Working Visa & $Z$ 字签证, 发给申请在中国境内工作的人员 \\
\hline Q & Family Reunion Visa & $\begin{array}{l}\text { Q1 字签证, 发给因家庭团聚申请入境居留的中国公民的家庭 } \\
\text { 成员和具有中国永久居资格的外国人的家庭成员, 以及 } \\
\text { 因寄养等原因申请入境居留的人员; Q2字签证, 发给申请入 } \\
\text { 境短期探亲的居住在中国境内的中国公民的亲属和具有中 } \\
\text { 国永久居留资格的外国人的亲属 }\end{array}$ \\
\hline
\end{tabular}

Source: The State Council of the People's Republic of China (2013). http://cs.mfa.gov.cn/wgrlh/lhqz/sblhqz_660598/ t1060665.shtml 
visa are barred from entering China for at least five years (Standing Committee of the Eleventh National People's Congress 2012). In cases where the African husband is deported, family stability and security is disrupted.

The key informant Mr Y., an African community leader, described knowing of 'at least 100 cases' where African husbands had been deported from China. He described how many Africans do not apply because of high transaction costs, the annual renewal requirement and the potentially long distances of travel needed to reach their Chinese partner's hometown. Legal precarity arises at the intersection of global and local migration policies, conditioning homing practices and often negatively affecting family life. Once deported, some African men are unable to return to China, leaving their partners behind as de facto single mothers to care for their children. This inability to return echoes the (im)mobility literature, which focuses on people's inability to achieve their mobility aspirations (Carling and Schewel 2018; Coulter, van Ham, and Findlay 2016). As African men are primarily motivated to travel to China for economic pursuits, deportation and repatriation often means the loss of opportunities to earn a livelihood. This reduces their capacity to provide for their now transnational family, who often must stay behind in China. $\mathrm{Mr}$ Y. further alleged that due to financial constraints, single mothers subsequently abandon their children. Some mothers had even approached him and asked whether he or someone else might 'want to buy [their] babies'. While it was impossible for us to verify such statements, the narratives offered suggest the difficult circumstances that these families face when African husbands are repatriated.

Internal migration has emerged as an important factor (Cheng and Selden 1994). In China, the hukou system is tied to one's birthplace and forms the basis of resource allocation, distribution of services and job opportunities (Fan 2002; Zhu and Qiang 2020, this issue). Hukou status determines eligibility for critical social resources, including education, healthcare and housing. Non-local hukou status prevents many internal migrants from accessing public resources. Thus, the separation of these families can severely undermine the remaining parent's capacity to care for their children in the absence of any temporary or long-term welfare support by the state. Furthermore, a return to the maternal birthplace does not ensure hukou registration for the children: this decision rests at the discretion of local officials, especially in the absence of official marriage registration (Haugen 2014).

Families face trade-offs regarding legal and economic risks. Mrs C. described her family's situation when her Nigerian husband was caught with an expired $M$ visa during our fieldwork period. A customer placed an order for 200 pairs of shoes with their shop, which would have generated a profit of approximately $10 \%$ of their family's monthly expenditure (RMB $500(£ 59)$ ). Her husband successfully delivered the shoes, but was caught by undercover police while exiting the trading mall where the shop was located. Mrs C. described how she begged the police not to take him but knew it was useless'. Their daughter, ten months old, was 'just there watching. She was scared and cried out loud'. Her husband was detained for two months, and she was unable to see him or deliver essential medication. He was subsequently deported.

Mrs C. expressed intense feelings of guilt and regret, blaming herself: 'I ask myself why had I not been capable of handling all these things. Then my partner would not have needed to take this risk and get caught'. Mrs C. insisted on running the shop as usual and believed she 'had to be strong in front of people'. A few months later, when we 


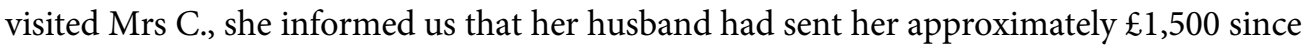
his deportation. The majority was for buying goods, but a proportion was for raising her two daughters (one born from her previous marriage). This is reminiscent of reverse remittances, money flows from migrants' country of origin to the countries where they migrated. This phenomenon is observed where migrants are in precarious conditions (Mazzucato 2009) and reflects the pendular reconfigurations of family life across distances (Chen 2021, this issue). The couple plan for Mrs C. to travel to Nigeria to register a legal marriage, and then apply for permanent residency in Nigeria illuminating how the interrupted process of home-making gives way to an aspirational dream of 'homing' in the future (Boccagni 2017 WP:16).

Mrs C.'s story is not uncommon among Guangzhou's African-Chinese migrant community. During our interviews, a sense of foreboding was palpable when the topic of visas arose. Our participants expressed concern about growing difficulties and complications in visa applications, except among higher-SES participants in the sample, highlighting the intersectionality of legal and economic precarity. Mr P., a self-employed Congolese trader, observed that 'right now... Guangzhou is trying to reduce the number of illegal foreigners who are living here... They are chasing away those people around here, and [making] things ... complicated'. He also expressed his belief that this was likely to drive more African men to marry Chinese women:

First of all, a lot of people who are married to Chinese [did so] only because they wanted to get a Chinese visa ... Because you know, applying [for] a Business [M] visa is complicated. Because you must have a company back home... And you must have all the documents. You must pay taxes, different taxes, back home. And also, each month, we have some Chinese government taxes [that need] to be paid. Some people think it's a lot and cannot accept it, cannot deal with it. They prefer to take a shortcut. That means that if I have a relationship with a Chinese woman, and I get married, I can have all the advantages without paying any money. (Mr P., 6 August 2016)

This account illustrates how precarity activates a kind of opportunism, echoing the sociolegal scholarship on migrants' 'legal consciousness' in the face of oppression - how people understand and navigate the law (Nielsen 2004). Ethnographic studies on Burmese refugees in South Korea (Lee 2018) and Burmese-Chinese minorities in Myanmar (Ho and Chua 2016) document how legal oppression is navigated 'to recuperate subaltern political subjectivity' (898). Conscious of their conditional legal status, migrants 'outwit' legal oppression by adopting spatial strategies of recognition and protection. Indeed, legal precarity may lead to Africans in China identifying 'shortcuts', incentivizing African-Chinese marriages as a spatial-intimate practice to circumvent the strict business visa restrictions. Marriages can involve both love and self-interest and, more poignantly, reveal the intersections between intimacy and citizenship, jointly embedded in legal and policy practices (D'Aoust 2013). The more stringent immigration law and regulations promulgated by the Chinese government introduced higher fines for the 'illegal activities' of foreigners while barring the foreign spouses of Chinese citizens from working rights (Bork-Hüffer and Yuan-Ihle 2014; Standing Committee of the Eleventh National People's Congress 2012); thus, marriage is not a legally secure route for employment. Among lower-SES families where both spouses must work to survive, circumventing the system may emerge out of necessity. The interaction of hukou and immigration policies exacerbates the conditions of precarity experienced by these families. 


\section{Economic precarity and intimate family life}

Visa status, and its ensuing legal implications, restricts the employment opportunities of African men. Once married to Chinese women, these men can apply for the Q visa, but in practice, neither step provides an enduring sense of security or certainty. Unless an African man obtains Chinese citizenship, a rare occurrence for any foreigner (Pieke 2012), simply being married to a Chinese woman does not give him the right to work.

One study of interracial sexuality in Shanghai, noted that many foreign (white, Western) men feel emasculated in local Chinese contexts, where the native women are often more 'powerful, competent and autonomous than the men' (Farrer 2010, 86). Several participants in our study described how working restrictions disrupted their family's notions of gender roles - particularly masculinity - highlighting the ways that gender is negotiated as an aspect of homing. Mr P. explained during a joint couple interview:

First of all, you should understand that African men usually have power traditionally ... 95\% of African men will not accept the woman controlling everything ... that's why I say you have to check who's earning the money [at] home. Who's working? Who's got the [real] power?

(Mr P., 6 August 2016)

This expression of masculinity suggests that power dynamics between Chinese wives and African husbands are partly shaped by the ability to 'earn money'. For example, $\mathrm{Mr}$ A. (Nigerian, Family Reunion Q visa holder) expressed genuine perplexity: 'How can I depend on my wife?' Our fieldwork revealed discontent among African husbands rather than the compromised masculinity observed in other ethnic and cultural contexts (Charsley 2005). The husbands in our sample took charge of commercial decisions in their family businesses. Given the opportunity, the family's preference would be to secure the male partner's breadwinner role legally. For example, Mr P. articulated that having financial responsibility for his family would enable him to establish a 'solid image' as a patriarchal and responsible father. Yet being unable to work legally seriously challenged his sense of self and responsibility for his family.

One day I will be able to settle here, each time they give me two years, right? OK, the first time, the second time, the third time, and [another] day maybe, they will ask me, What are you doing here? How are you living? Because you are not [supposed to be] working, you are nothing here, how [do] you live here? (Mr P., 6 August 2016)

In the end, Mr P. decided to keep his M visa even though he was married to a Chinese citizen. This case was unique as Mr P. had notably higher SES than our other participants. Maintaining his $\mathrm{M}$ visa allows him to stay in China, irrespective of whether he is married to a Chinese woman, with the right to engage in trade or commercial activities. His explanation offers insight into the logic of how Chinese immigration enforcement might view the long-term presence of an African husband with a Chinese wife who holds a nonworking (Q) visa. From Mr P.'s perspective, all African males from diverse high- or low-SES African countries choose to work continuously irrespective of their visa status.

Despite holding valid visas, the experience of regular monitoring by immigration authorities was common among participants, disrupting daily life and furthering conditions of precarity and insecurity under the threat of surveillance. As Mrs P. described:

You know, sometimes the immigration officer comes. Because we registered, they know where we live. They come to our apartment to check our living and working situation ... 
There is a foreigner management office in the community. If you apply [for] the temporary residence permit for foreigners, they know where you live ... the Chinese government likes to do regular checks. They come to [see] how [your] foreign friends are living in China ... [but] if he has got [a Business Visa], [Mr P.] fears nothing. (Mrs P., 6 August 2016)

The situation creates (il)legalities of work and residence through the multi-tiered visa system. Economic precarity emerges in the bifurcation of secure labour (Commerce and Trade $\mathrm{M}$ visa) and domestic responsibilities in intimate family life (Family Reunion $\mathrm{Q}$ visa). The economic precarity found among our respondents is rarely reported by the previous literature on marriage between Chinese citizens and foreign nationals in China, which places more emphasis on gender, sexuality and the interactions of cultural norms and values. Furthermore, the literature on cross-cultural marriages often focuses on foreign nationals from Western developed countries, typically a dyad involving a Caucasian white male of middle-class standing and a Chinese woman (Wang 2014; Farrer 2010).

In contrast, the families in our study highlight the (financial) insecurities from a lack of legal status. Lan (2015b) illustrated how undocumented Nigerian traders worry that their business and property could be taken by their Chinese partners if deported, as their irregular status' from overstaying could prevent the legal registration of their marriage in China. This study goes further to argue that even legally married African men could be deported if they do business in Guangzhou with the Q visa. Formal marriage was not enough to protect our respondents from economic precarity. The documented transformations and negotiations of gender roles through multiple interstices of vulnerability further introduces social dimensions to precarity and intimate family life among the families in our study.

\section{Social precarity and intimate family life}

Social precarity describes families' experiences of uncertainty regarding their place in the host community. It encompasses their sense of social inclusion, safety and belonging as an ongoing aspect of homing. Almost all participants described experiencing multiple forms of discrimination and prejudice, reproduced through media and social interactions in public life.

A web search using the word 'Africans' ( fei zhou ren) of Chinese media coverage from 2008 to 2015 revealed negative depictions and associations including 'violent', 'drugs', 'poor' and 'AIDS'. One article, under the headline 'Foreigner's sudden death in police station in Guangzhou' (Di 2012), reported that a Nigerian man 'died suddenly' in a police station after being detained for a dispute with a taxi driver. No cause of death was given. Similarly, another article entitled 'Foshan: Black man's fall to death causes a gathering of foreigners' (Feng 2014), described an incident where an African suspected of substance misuse and drug dealing 'fell to his death' after being chased by the police, sparking a public assembly of about 50 Africans protesting the treatment of Africans in Guangzhou. An article entitled 'Chinese women participate in drug dealing with their African lovers' (Fu 2014) reported 18 court cases of cross-border drug trafficking between 2010 and 2013 and portrayed African men as 'dangerous' and 'exploitative'.

Our African participants were cognisant of how the media and public perceived them. Mr Bo described how local Chinese discriminate against him due to his dark skin. He attributes this largely to ignorance, believing that opinions about Africans would improve if the Chinese recognised Africans as a diverse group. These views were corroborated by their Chinese partners. Mrs L. expressed frustration about some Chinese people asking her 
whether 'Africans really live in trees'. Mrs C. described people's 'curiosity' about her child, and how people would ask her why her child's skin is a different colour. 'People automatically' assume that she married an African 'for his money' or, in contrast, pity her because Africans (heigui or 'black devil') are portrayed as poor (qionggui or 'poor devil') and 'unhygienic'. Mrs N. irately pointed out that most African men dress better than local Chinese men.

Our participants described instances of blatant discrimination involving personal attacks and open hostility. Mrs H. described how a Chinese questioned why she would marry a 'poor and dirty' black man. Parents tell their children not to play with her children because of their mixed heritage. She felt indignant and argued that if a country decides to let people in, they should be accepted. She was exasperated by how people treat all Africans as if they were identical: 'there are both good and bad people in the group you know!' $\mathrm{Mr}$ O. detailed how when he and his wife went to register their marriage, the government officer asked his wife, 'Why would you marry a black man?' Mrs L. was asked whether she had 'married [her African husband] because he was good in bed'. She also complained that when they went to the beach as a family, 'people would flee from her husband' when he took off his shirt. Personal choices are constantly questioned and intimate family life intruded upon by these discriminatory remarks.

The couples' children are also subjected to bigotry. Mrs L. recalled how people on the subway stare at her children. There have been occasions when people touched her children's hair without consent and commented 'Oh, how does the mao (animal's hair) grow like this?' Similarly, Mrs C. described her fear and reluctance to take her baby out of their home simply because she wanted to 'avoid conflicts' on the street, where her daughter was called 'a bastard'. Likewise, Mr Y. shared that he is called a heigui daily and that his children are bullied at school for being 'dark-skinned'.

Discrimination is interwoven into the sphere of work. While many Chinese live off of business with Africans, they also curse them. African traders may receive substandard goods despite paying in full. When traders tried to report disputes, the police were 'totally unhelpful'. Sometimes, trading disputes lead to violence. Mrs L. witnessed a Chinese mob beating up an African for reporting a trading dispute to the police.

Discrimination is also evident in the housing market. Partly due to a lack of the official documents required for renting, some of our informants rented apartments in chengzhongcun (village-in-the-city), communities of low-cost residential units situated at the margins of the city and characterised by dilapidated housing and infrastructure, and poor public security (Tian 2008). Typically, domestic migrants occupy chengzhongcun. Mrs C. complained that her landlord charged her family a higher rate than other occupants due to her husband's skin colour. Similarly, Mr Y. complained that renting apartments in Guangzhou was difficult for Africans and their families, and that police restricted the areas and types of apartment that Africans could rent. Interestingly, $\mathrm{Mr}$ Y. emphasised that his skin colour was not the sole issue. He claimed that a person's regional origins were important: an African-American renter would be treated better. $\mathrm{Mr} \mathrm{O}$. had been asked by the police to move to another neighbourhood several times despite procuring all the required documents. He claimed that even with proof of residence, some landlords refuse to rent to Africans, even those with Chinese wives. $\mathrm{Mr}$ Bo, on the other hand, insisted that racial discrimination was not entirely the reason why landlords did not like renting their properties to Africans. Instead, he suggested, it 
may be the 'regulations' requiring landlords to accompany foreigners to register at the Neighbourhood Committee that deter landlords from leasing apartments to Africans. The absence of any racial discrimination ordinance or anti-discrimination laws contributes to the erosion of security for these families, linking legal and social precarity.

African migrants are often rejected not only by Chinese society at large, but often by their partners' extended family. Although others noted that African migrants could build support networks in Guangzhou and transnationally via trade networks (BorkHüffer et al. 2016; Castillo 2016; Haugen 2013), we found that sources of social support were neither sufficient nor effective in meeting families' needs. Almost all of our interviewees had never heard of, nor received non-profit organisations' (NPO) services. Perhaps due to perceived societal and personal stigma, they are reluctant to seek informal support from extended family members.

We return here to the case of Mrs C., who was reluctant to seek help from her family following the arrest of her partner. Her parents are over 60 and had raised eight children. She thought that they had already sacrificed a lot, explaining, 'I don't want them to know this time. I didn't choose the wrong guy'. Regarding other close family members, Mrs C. said that her siblings were unreliable or would laugh at her for 'being a fool again', referring to her first, failed marriage. One of them suggested that she abandon her daughter, but she refused. She would raise her, even if her partner disappeared in the future. She would find a job rather than go back to relying on her extended family.

Mrs C.'s response echoes those of other participants when asked about their relationship with and expectations of their extended Chinese family, especially their parents. $\mathrm{Mr}$ Bo was rejected by his wife's family in the beginning. Her father did not want his daughter to move far away. Similarly, Mrs Z.'s family did not approve of her marriage to an African, because he came from a 'poor' country and a different cultural background. Even when spouses' parents eventually gave in, some warned that 'You cannot regret this'. Thus, when the families encounter difficulties, historical familial disapproval, combined with the desire to prove self-sufficiency, prevents help-seeking from Chinese family networks. We did not find evidence of engagement with transnational African familial networks, although Mrs C.'s willingness to consider migration to Nigeria to join her deported husband and build a new life at least suggests the possibility that transnational familial networks may be mobilised for family reunion purposes, and future homing away from home, as it were.

\section{Opportunities in the face of precarity?}

While these narratives depict the daily challenges faced by African-Chinese families, opportunities activated by these conditions of precarity also emerged. We do not intend to suggest that precarity per se benefits these families and is therefore good. Rather, we interrogate precarity, to document the multiple ways in which precarity and processes of precarization are taken up, negotiated and even implicitly challenged by these families (Castillo 2016; Harker 2012; Wilson and Yochim 2015).

Despite hardships, some African participants still regarded China as 'a better place for living and business' than their own country. Mr Y. complained that in his hometown in Nigeria days without a power failure are rare and the 'government was broken'. He felt relieved to be in China, where there is at least running water and electricity, and where 
children are entitled to free and compulsory education in their maternal hometown. $\mathrm{Mr}$ Y.'s four children thus receive their education in his wife's hometown, a small remote municipal city on the northern border of Guangdong province. This family chose for the wife to return to live with her mother due to the living costs for a family of four children. This option is considered a last resort for many small family business operators, where the labour input of both mother and father is important to sustainability.

Several Chinese wives shared that they felt higher levels of respect, autonomy and satisfaction in their relationships, contradicting earlier narratives of discrimination and rejection. For some, romance and adventure were part of the narrative. Recalling her first encounter with her husband, Mrs C. described it as a 'typical Hollywood movie scene'. She had met her current partner two years prior at a bus stop. He immediately started talking to her even though she did not understand a word he said. He accompanied her and sat with her at McDonald's. 'I wasn't in a good mood, but somehow he made me feel better'. They have been together ever since. Furthermore, comparing her Nigerian husband to her ex-husband, the father of her eight-year-old daughter, Mrs C. said that 'marrying an African is different. For example, if somebody said, 'Your wife is pretty', A Chinese man would say, 'Not really'. But [my current] partner will say, 'Yes, thank you". These gestures made her feel more confident, loved and relaxed. Before meeting her current partner, Mrs C.'s mother introduced her to several Chinese men. They all asked her not to bring her daughter into the relationship. Only her current Nigerian partner said, 'Your daughter is [also] mine and I will raise her for you'. This stood in contrast to traditional Chinese cultural stigma concerning remarriage, where children from former marriages are often considered a burden (Cheung and Liu 1997), and made her feel especially loved.

The Chinese female participants often found themselves in relationships and marriages with African men serendipitously. Being a rural-to-urban migrant herself, Mrs C. came to Guangzhou in search of upward economic mobility, much like her Nigerian partner. The intersection of these two migrant pathways suggests how the dynamics of low-end globalisation mobility facilitates such encounters. In addition to finding economic independence, Mrs C. discovered romantic love, and embarked on new experiences including dating a Nigerian man. She has since re-evaluated romantic love. There was a sense of satisfaction and contentment when Mrs C. spoke about her current partnership. Unlike her previous marriage, her current relationship seems to generate important and positive meaning.

Our participants alluded to feelings of self-liberation and empowerment in their relationships. Mrs P. described how her parents were vehemently against her relationship with Mr P. initially, threatening to cease paying her tuition fees for her final year of college. She had defiantly left her hometown and gone to Guangzhou with Mr P. Both have since become financially independent. She returned to her hometown triumphantly and announced to her mother that she did not need her money. Mrs P. laughed and said it was probably at this point that her mother had no choice but to give up and accept their relationship.

Farrer's (2010) historical ethnographic work situates interracial sexuality and gender relations in China within a genealogy of change across recent decades. In the 1980s, scholarship depicted Chinese women losing jobs for dating foreign men in the 1980s. This proceeded to an 'opening up of sexual culture in China during the 1990s' (Farrer 2010, 81), and to the contemporary emplacement of 'interracial sexual fields' in urban China since 
2000. Our study reflects further nuance of 'ethnosexual frontiers' in China, 'where ethnicity is sexualized, and sexuality is racialized, ethnicized and nationalized' (Nagel 2003, 14) distinct from intercultural marriages between Chinese women and Western white men. The processes of low-end globalisation set in motion partly by the economic reforms within China since the 1980s contribute to spaces of overlapping mobilities which give rise to new mixed-heritage families.

\section{Conclusion: a way forward}

This article has explored the dynamics between multiple intersecting domains of legal, social and economic precarity, and the homing processes that form intimate family life for African-Chinese families in Southern China. We found that the structuring forces of precarity induced by elements of low-end globalisation and manifested through national and local policies and institutions, create both challenges and opportunities for families of overlapping mobilities.

Although precarity circumscribes the lives of these families, manifesting as insecurity, uncertainty and vulnerability, our findings also suggest how the narratives of these families defy simplistic characterisation. These families cultivate living strategies that invoke hope for the future, strength and adaptation in the face of adversity, and resourcefulness and partnership in intimate family life. Some perceive their relationships to be born out of convenience: for Chinese women, marrying African men may mean upward economic mobility and stability; for African men, marrying Chinese women may mean a more stable visa status. Such unions may offer a way to challenge and subvert the precarity they encounter individually. In the face of precarity, these families demonstrate flexibility in overcoming daily challenges to advance their family's security, creating a shared sense of belonging in these processes of present day - and for some, future aspiration of - homing.

Nevertheless, the cumulative effects of multiple precarity - legal, economic and social require recognition, especially considering the constant threat of deportation hanging over fathers, which may destabilise the livelihood and security of these families. As deportees are prevented from entering China for at least five years, they become unable to fulfil their intended roles as husbands and fathers. Constraints resulting from austere visa restrictions, prejudice and discrimination, and access to public resources critical to individuals' wellbeing, such as housing, healthcare and education, were common themes underlying these families' narratives. Despite intentions to maintain self-reliance and attempts to be entrepreneurial, many of these families are forced to struggle to navigate through a complex and rigid system in their quest to provide stability, resources and security to their children.

Overlapping mobilities of differential inclusion and citizenship status thus intersect with conditions of precarity. The influence of legal and policy frameworks outlined in the current study are similar to other cultural settings, for example Syrian migrants in Turkey face the increasing need to engage in illegal trade or activities (Baban, Ilcan, and Rygiel 2017). The regulations imposed on eligibility to work and residency status put many African migrants in difficult positions, with some resorting to activities deemed criminal, facing deportation and leaving behind young children and their Chinese partners.

In consideration of these barriers, the private social territory (Boccagni and Brighenti, 2017) of the family becomes the site where people are expected to shoulder responsibility for the consequences of public dispossession (Wilson and Yochim 2015, 673). 
Furthermore, the overlapping mobilities of international and rural-to-urban domestic migration enhance the complexity of these families' daily lives as they negotiate various institutions in the host community. Rural-to-urban migrants are treated and represented as 'outsiders' (Qian and Florence 2021, this issue), carrying the labels of 'temporary migrants', 'second-class citizens' or 'peasants', and often targeted by discrimination and unfair policing (Han 2010). Societal reactions to forming relationships with African migrants - also outsiders - may further stigmatisation.

The growing presence of African migrants and new practices of family-making directly challenge the openness of Guangzhou as a host society, and the receptiveness of its various policies to diverse migrants and families under conditions of circumstantial migration (Carling and Haugen 2021, this issue). As children from these families grow up, they will likely navigate multiple forms of precarity- from public institutions such as schools and work, to more intimate, personal levels such as peer relationships and their own identity development. Unless structural-level and interpersonal changes are stimulated to address the needs of this growing population, adversity caused by conditions of precarity is inevitable.

Our findings should be interpreted in light of several limitations. First, our sample is not representative of either Chinese internal migrants or African migrants. African students, for example, whose experiences in China may be different, were not included in our study. Second, our study was conducted only in Guangzhou, one popular destination for African migrants. Future studies should explore the conditions and experiences of family-formation among African migrants in other Chinese localities.

To conclude, low-end globalisation acts as a catalyst generating overlapping mobilities within formal and informal migration regimes. The overlap between the macro-economic and the intimate dimensions of human experiences, including romance, marital unions and family-formation with children, will likely continue to grow. Our study contributes to current empirical scholarship on Africa-China encounters, highlighting the significance of the overlapping mobilities and precarity generated by the mobility processes of low-end globalisation. Theoretically, where some have traced 'precarity as originary to capitalism' (Millar 2017, 6), we consider the prevalence of precarization under 'socialism with Chinese characteristics', highlighting how existing institutions and policies in host communities, or their absence, influence intimate family life. Furthermore, Alberti et al. (2018) suggest that in emergent processes of precarization, the power still possessed by workers at the points of production must not be overlooked. We extend this argument's relevance to the domestic sphere, where parents, spouses and familial networks of differing migration and labour regimes coalesce in engaged struggles and resistance through work and homing. The study further contributes to our understanding of precarity by showing how precarious labour and precarious living (Neilson and Rossiter 2008) intersect in specific geopolitical spaces/locales. Although conditions of precariousness spawn hardship, they also give rise to a forging of meaning, stimulating opportunities for upward mobility and, for some, unexpected romance and independence.

\section{Notes}

1. The term 'three illegals' refers to 'illegal entry, illegal residence, and illegal work' (Bodomo 2012; Li, Lyons, and Brown 2012). 
2. We adopt Boccagni's $(2017,10)$ theorisation where 'homing refers to the aggregate of micropractices whereby people try to make themselves at home in their life circumstances, and to the moral and emotional economies underpinning them'.

\section{Acknowledgement}

We would like to thank our research participants for sharing their time and experiences with us.

\section{Disclosure statement}

No potential conflict of interest was reported by the author(s).

\section{Funding}

This project was funded by the Government Matching Grant Scheme and the Stanley Ho Alumni Challenge Scheme, The University of Hong Kong (Project Number 208040057).

\section{ORCID}

Lucy Jordan (iD http://orcid.org/0000-0002-6415-8275

Andrew Pau Hoang (DD http://orcid.org/0000-0003-1561-2686

Cheryl H. K. Chui (D) http://orcid.org/0000-0002-3284-5724

\section{References}

Alberti, G., I. Bessa, K. Hardy, V. Trappmann, and C. Umney. 2018. "In, Against and Beyond Precarity: Work in Insecure Times." Work, Employment and Society 32 (3): 447-457. doi:10. 1177/0950017018762088.

Baban, F., S. Ilcan, and K. Rygiel. 2017. "Syrian Refugees in Turkey: Pathways to Precarity, Differential Inclusion, and Negotiated Citizenship Rights." Journal of Ethnic and Migration Studies 43 (1): 41-57. doi:10.1080/1369183X.2016.1192996.

Bauder, H. 2006. Labor Movement: How Migration Regulates Labor. New York: Oxford University Press.

Boccagni, P. 2017. Migration and the Search for Home. London: Palgrave.

Boccagni, P., and A. M. Brighenti. 2017. "Immigrants and home in the making: thresholds of domesticity, commonality and publicness." Journal of Housing and the Built Environment 32: 1-11. doi: 10.1007/s10901-015-9487-9.

Bodomo, A. 2012. Africans in China: A Socio-Cultural Study and its Implications on Africa-China Relations. New York: Cambria Press.

Bodomo, A. 2015. "Africans in China: Guangzhou and Beyond - Issues and Reviews." Journal of Pan African Studies 7 (10): 1-10.

Bork-Hüffer, T., B. Rafflenbeul, Z. Li, F. Kraas, and D. Xue. 2016. "Mobility and the Transiency of Social Spaces: African Merchant Entrepreneurs in China." Population, Space and Place 22 (2): 199-211. doi:10.1002/psp.1900.

Bork-Hüffer, T., and Y. Yuan-Ihle. 2014. "The Management of Foreigners in China: Changes to the Migration law and Regulations During the Late Hu-Wen and Early Xi-Li Eras and Their Potential Effects." International Journal of China Studies 5 (3): 571-597.

Bourdieu, P. 1963. Travail et Travailleurs en Algérie. Paris: Mouton.

Braun, V., and V. Clarke. 2006. "Using Thematic Analysis in Psychology." Qualitative Research in Psychology 3 (2): 77-101. doi:10.1191/1478088706qp063oa.

Butler, J. 2004. Precarious Life: The Powers of Mourning and Violence. London: Verso. 
Cai, X., and X. Su. 2021. "Dwelling-in-traevlling: Western Expats and the Making of Temporary Home in Guangzhou, China." Journal of Ethnic and Migration Studies 47 (12): 2815-2832. doi:10.1080/1369183X.2020.1739392.

Carling, J., and H. Ø. Haugen. 2021. "Circumstantial Migration: how Gambian Journeys to China Enrich Migration Theory.” Journal of Ethnic and Migration Studies 47 (12): 2778-2795. doi:10. 1080/1369183X.2020.1739385.

Carling, J., and K. Schewel. 2018. "Revisiting Aspiration and Ability in International Migration.” Journal of Ethnic and Migration Studies 44 (6): 945-963. doi:10.1080/1369183X.2017.1384146.

Castillo, R. 2014. "Feeling at Home in the "Chocolate City": an Exploration of Place-Making Practices and Structures of Belonging Amongst Africans in Guangzhou." Inter-Asia Cultural Studies 15 (2): 235-257.

Castillo, R. 2016. “'Homing' Guangzhou: Emplacement, Belonging and Precarity among Africans in China." International Journal of Cultural Studies 19 (3): 287-306. doi:10.1177/ 1367877915573767.

Charsley, K. 2005. "Unhappy Husbands: Masculinity and Migration in Transnational Pakistani Marriages." Journal of the Royal Anthropological Institute 11: 85-105. doi:10.1111/j.1467-9655. 2005.00227.x.

Chen, J., and J. Bao. 2021. "Chinese 'Snowbirds' in Tropical Sanya: Retirement Migration and the Production of Translocal Families." Journal of Ethnic and Migration Studies 47 (12): 2760-2777. doi:10.1080/1369183X.2020.1739377.

Cheng, T., and M. Selden. 1994. "The Origins and Social Consequences of China's Hukou System.” The China Quarterly 139: 644-668.

Cheung, C., and E. Liu. 1997. "Impacts of Social Pressure and Social Support on Distress among Single Parents in China." Journal of Divorce \& Remarriage 26 (3-4): 65-82. doi:10.1300/ J087v26n03_06.

Coulter, R., M. van Ham, and A. M. Findlay. 2016. "Re-thinking Residential Mobility: Linking Lives Through Time and Space." Progress in Human Geography 40 (3): 352-374. doi:10.1177/ 0309132515575417.

D’Aoust, A. M. 2013. “In the Name of Love: Marriage Migration, Governmentality, and Technologies of Love." International Political Sociology 7 (3): 258-274. doi:10.1111/ips.12022.

Di, C. 2012. "A Foreigner Suddenly Dead in Police Station in Guangzhou." People's Daily Online. http://news.qq.com/a/20120620/000051.htm.

Fan, C. 2002. "The Elite, the Natives, and the Outsiders: Migration and Labor Market Segmentation in Urban China." Annals of the Association of American Geographers 92 (1): 103-124. doi:10. 1111/1467-8306.00282.

Farrer, J. 2010. "A Foreign Adventurer's Paradise? Interracial Sexuality and Alien Sexual Capital in Reform Era Shanghai.” Sexualities 13 (1): 69-95. doi:10.1177/1363460709352726.

Feng, L. 2014. "Foshan: Black Man's Fall to Death Causes a Gathering of Foreigners.” Southern Metropolis Daily. http://gd.sina.com.cn/news/s/2014-06-18/0731107026.html.

Feng, D., H. Zhu, and Y. Wang. 2021. "Agency and Mobilty in the Context of DevelopmentInduced Migration: the Case of Three Gorges Out-Migrants." Journal of Ethnic and Migration Studies 47 (12): 2745-2759. doi:10.1080/1369183X.2020.1739375.

Fu, M. 2014. "Chinese Women Participate in Drug Dealing with their African Lovers." China News. http://www.chinanews.com/fz/2014/06-26/6322984.shtml.

Gao, Q. 2021. "Reconstituting the Neoliberal Subjectivity of Migrants: Christian Theo-Ethics and Migrant Workers in Shenzhen, China." Journal of Ethnic and Migration Studies 47 (12): 2725-2744. doi:10.1080/1369183X.2020.1739374.

Han, D. 2010. "Policing and Racialization of Rural Migrant Workers in Chinese Cities." Ethnic and Racial Studies 33 (4): 593-610. doi:10.1080/01419870903325651.

Harker, C. 2012. "Precariousness, Precarity, and Family: Notes from Palestine." Environment and Planning A: Economy and Space 44 (4): 849-865. doi:10.1068/a4478.

Haugen, H. Ø. 2012. "Nigerians in China: A Second State of Immobility." International Migration 50 (2): 65-80. doi:0.1111/j.1468-2435.2011.00713.x. 
Haugen, H. Ø. 2013. “China’s Recruitment of African University Students: Policy Efficacy and Unintended Outcomes." Globalisation, Societies and Education 11 (3): 315-334. doi:10.1080/ 14767724.2012 .750492$.

Haugen, HØ. 2014. “Chinese Family Planning Policies and Transnational Families.” Paper Presented in a Panel on 'Interpersonal Relations Between Africans and Chinese in Guangzhou: Trust, Doubt and Betrayal in Business, Friendship, and Love."' The third international conference on Chinese in Africa/Africans in China, Guangzhou, China: Jinan University, 12-13 December 2014, 185194.

Ho, E. L.-E., and L. J. Chua. 2016. "Law and 'Race' in the Citizenship Spaces of Myanmar: Spatial Strategies and the Political Subjectivity of the Burmese Chinese." Ethnic \& Racial Studies 39 (5): 896-916. doi:10.1080/01419870.2015.1081963.

Huynh, T. T., Y. J. Park, and A. Y. Chen. 2010. "Faces of China: New Chinese Migrants in South Africa, 1980s to Present.” African \& Asian Studies 9 (3): 286-306. doi:10.1163/ $156921010 X 515978$.

Jordan, L. P., G. DeVerteuil, J. Kandt, D. Manley, and Q. Wu. 2017. “On the Edge: Changing Geographies of the Global City Precariat in London and Hong Kong." Urban Geography 38 (10): 1459-1478. doi:10.1080/02723638.2016.1258205.

Kuo, L. 2015. “China's Xi Jinping Pledges $\$ 60$ Billion to Help Africa Solve its Problems its Own Way.” http://qz.com/565819/chinas-xi-jinping-pledges-60-billion-to-help-africa-solve-its-problems-itsown-way/.

Lan, S. 2015a. "State Regulation of Undocumented African Migrants in China: A Multi-Scalar Analysis." Journal of Asian and African Studies 50 (3): 289-304. doi:10.1177/0021909614531903.

Lan, S. 2015b. "Transnational Business and Family Strategies among Chinese/Nigerian Couples in Guangzhou and Lagos.” Asian Anthropology 14 (2): 133-149. doi:10.1080/1683478X.2015. 1051645.

Lee, S. K. 2018. "From Political Activists to Social Entrepreneurs: Burmese Refugees in South Korea.” Journal of Refugee Studies 31 (5): 371-389.

Li, Z., M. Lyons, and A. Brown. 2012. "China's 'Chocolate City': An Ethnic Enclave in a Changing Landscape.” African Diaspora 5: 51-72.

Li, Z., L. J. C. Ma, and D. Xue. 2009. "An African Enclave in China: The Making of a New Transnational Urban Space.” Eurasian Geography and Economics 50 (6): 699-719.

Lin, Y. C. J. 2011. Fake Stuff: China and the Rise of Counterfeit Goods. London: Routledge.

Li, W., L. Lo, Y. Lu, Y. Tan, and Z. Lu. 2021. "Intellectual Migration: Considering China." Journal of Ethnic and Migration Studies 47 (12): 2833-2853. doi:10.1080/1369183X.2020.1739393.

Lyons, M., A. Brown, and Z. G. Li. 2012. "In the Dragon's Den: African Traders in Guangzhou." Journal of Ethnic and Migration Studies 38 (5): 869-888. doi:10.1080/1369183X.2012.668030.

Marsh, J. 2014. “Afro-Chinese Marraiges Boom in Guangzhou: But will it be 'Til Death do us Part'?" http://www.scmp.com/magazines/post-magazine/article/1521076/afro-chinese-marriagesboom-guangzhou-will-it-be-til-death?page=all.

Mathews, G., G. L. Ribeiro, and C. A. Vega. 2012. Globalization from Below: The World's Other Economy. London: Routledge.

Mathews, G., and Y. Yang. 2012. "How Africans Pursue low-end Globalization in Hong Kong and Mainland China." Journal of Current Chinese Affairs 41 (2): 95-120.

Mazzucato, V. 2009. "Informal Insurance Arrangements in Ghanaian Migrants' Transnational Networks: The Role of Reverse Remittances and Geographic Proximity." World Development 37 (6): 1105-1115.

Millar, K. M. 2017. “Toward a Critical Politics of Precarity.” Sociology Compass 11 (6): 1-11.

Ministry of Education of the People's Republic of China. 2015. "China Attracts more Overseas Students in 2014.” http://www.moe.edu.cn/publicfiles/business/htmlfiles/moe/moe_2809/ 201503/185164.html.

Nagel, J. 2003. Race, Ethnicity And Sexuality: Intimate Intersections, Forbidden Fruits. New York: Oxford University Press.

Neilson, B., and N. Rossiter. 2008. "Precarity as a Political Concept, or, Fordism as Exception." Theory, Culture, and Society 25 (7-8): 51-72. 
Nielsen, L. B. 2004. License to Harass: Law, Hierarchy, and Offensive Public Speech. Princeton, NJ: Princeton University Press.

Osanami Törngren, S., N. Irastorza, and M. Song. 2016. “Toward Building a Conceptual Framework on Intermarriage.” Ethnicities 16 (4): 497-520. doi:10.1177/1468796816638402.

Pieke, F. N. 2012. "Immigrant China." Modern China 38 (1): 40-77.

Puar, J., L. Berlant, J. Butler, B. Cvejic, I. Lorey, and A. Vujanovic. 2012. "Precarity talk: A virtual round table with Lauren Berlant, Judith Butler, Bojana Cvejić, Isabell Lorey, Jasbir Puar, and Ana Vujanović.” TDR: The Drama Review 56 (4): 163-177.

Qian, J., and E. Florence. 2021. "Migrant Worker Museums in China: Public Cultures of Migrant Labour in State and Grassroots Initiatives." Journal of Ethnic and Migration Studies 47 (12): 2706-2724. doi:10.1080/1369183X.2020.1739373.

Ribeiro, G. L. 2006. “Economic Globalization from Below.” Etnográfica 10 (2): 233-249.

Schierup, C. U., and M. B. J. Jørgensen. 2016. "An Introduction to the Special Issue. Politics of Precarity: Migrant Conditions, Struggles and Experiences.” Critical Sociology 52 (7-8): 947958. doi:10.1177/0896920516640065.

Standing Committee of the Eleventh National People's Congress. 2012. Exit and Entry Administration Law of the People's Republic of China. http://www.fmcoprc.gov.hk/eng/fwxx/ wgrqz/t1055657.htm.

Tian, L. I. 2008. "The Chengzhongcun Land Market in China: Boon or Bane? A Perspective on Property Rights.” International Journal of Urban and Regional Research 32 (2): 282-304. doi:10.1111/j.1468-2427.2008.00787.x.

Wang, P. 2014. Love and Marriage in Globalizing China. London: Routledge.

Wang, J., and Y. Liang. 2016. “African Traders Leave Guangzhou.” http://m.cnreform.caixin.com/ $\mathrm{m} / 2016-08-31 / 100983867 . h t m l$.

Williams, A. M. 2013. "Mobilities and Sustainable Tourism: Path-Creating or Path-Dependent Relationships?” Journal of Sustainable Tourism 21 (4): 511-531. doi:10.1080/09669582.2013. 768252.

Wilson, J. A., and E. C. Yochim. 2015. "Mothering Through Precarity." Cultural Studies 29 (5-6): 669-686. doi:10.1080/09502386.2015.1017139.

Zhu, H., and J. Qian. 2021. "New Theoretical Dialogues on Migration in China: Introduction to the Special Issue." Journal of Ethnic and Migration Studies 47 (12): 2685-2705. doi:10.1080/ 1369183X.2020.1739372. 